\title{
Analysis of the ecological environment around 10000 a BP in Zhaitang area, Beijing: A case study of the Donghulin Site
}

\author{
XIA ZhengKai ${ }^{*}$, ZHANG JunNa $^{1}$, LIU Jing $^{1}$, ZHAO ChaoHong ${ }^{2}$ \& WU XiaoHong ${ }^{2}$ \\ ${ }^{1}$ School of Urban and Environmental Science, Peking University, Beijing 100871, China; \\ ${ }^{2}$ School of Archaeology and Museology, Peking University, Beijing 100871, China
}

Received June 7, 2011; accepted August 5, 2011; published online October 1, 2011

\begin{abstract}
The transition from Paleolithic to Neolithic around 10000 a BP was a significant event in human history. We have analyzed the paleoenvironment in the Zhaitang area (Beijing) based on samples from an early Neolithic site at Donghulin. This site is considered to demonstrate the Paleolithic-Neolithic transition in this area. The site yielded burials with several human skeletons, known as "Donghulin man". We conducted a geomorphological and quaternary geological investigation in the Donghulin area, and also analyzed sediments and pollen, enabling us to discuss the living environment of the local people. Donghulin man lived mainly from 11100-9600 cal a BP; a period of warming following the Younger Dryas. The climate was good, the land was covered by dry temperate grassland, and later, wet temperate meadow steppe. "Donghulin man" usually inhabited the floodplain; this was flat, warm, and wet, with abundant plants and animals for a favorable living environment. Our research helps to rebuild the living environment of humans in the Beijing area around 10000 a BP, and to understand more about the environmental setting in north China during the Paleolithic-Neolithic transition.
\end{abstract}

Donghulin man, Paleolithic-Neolithic transition, Younger Dryas, ecological environment

Citation: Xia Z K, Zhang J N, Liu J, et al. Analysis of the ecological environment around 10000 a BP in Zhaitang area, Beijing: A case study of the Donghulin Site. Chin Sci Bull, 2012, 57: 360-369, doi: 10.1007/s11434-011-4772-9

"Donghulin man" was first found in 2003, in the Zhaitang Basin, $60 \mathrm{~km}$ from Beijing; in the area of the famous Malan loess sediments. Since 1923, many Quaternary geomorphologic and geologic investigations have been conducted in the area by geologists and geographers. Their work included research into fluvial landform evolution, loess deposition, and physiographic stages. As a result, the Zhaitang Basin became an important area in north China for research into stratal and landscape evolution during the Epipleistocene [1-7].

In 1966, Hao found some poorly-fossilized human bones and shell necklaces on the terrace 3 above the Qingshui River [8]. The Institute of Vertebrate Paleontology and Paleoanthropology of the Chinese Academy of Sciences carried out a dig, and their preliminary hypothesis was that this was a Neolithic burial site [9]. Between 2000 and 2008,

*Corresponding author (email: xiazk@urban.pku.edu.cn) the site was excavated many times by researchers from the School of Archaeology and Museology of Peking University, and from the Institute of Cultural Relics of Beijing City. It yielded stone implements, animal bones, and early pottery, as well as ashes and fireplaces. Preliminary results again indicated that it was a Neolithic site. Two complete human bones were unearthed from coinstantaneous tombs; the past human inhabitants were named "Donghulin man". ${ }^{14} \mathrm{C}$ dating indicated an age of 11100-9600 cal a BP [10].

Many early Neolithic sites dating from 9000-12000 a BP have now been found in the North China area. These include the Nanzhuangtou Site in Xushui, the Yujiagou Site in Yuanyang, Hebei Province; the Donghulin Site in Mentougou, the Zhuannian Site in Huanrou, Beijing; and the Shizitan Site in Jixian, Shanxi Province [11,12]. Among these, only Donghulin includes stone artifacts, potteries, fire places, and graves. The Donghulin Site was occupied during the warm period following the Younger Dryas (traditionally the 
estimated age was $11000-10000$ a BP, the latest estimated age is 12900-11500 a BP) [13-16]. This is also recognized as the transitional period between the Paleolithic and Neolithic [17]. The Donghulin Site has therefore aroused attention all over the world. We hope that our research into its paleoenvironment will be helpful in exploring the characteristics and environmental background of the cultural transition from Paleolithic to Neolithic.

In 2002, Hao researched the strata, grain size, chemical composition, spore and pollen levels, and the relative abundance of snails, in a profile near the Donghulin Site [18]. He proposed that the climate of this area was cold and dry during the Epipleistocene, and was obviously warming up before $9281 \pm 120$ a BP. The average temperature of north China around 8500 a $\mathrm{BP}$ was probably $2-3^{\circ} \mathrm{C}$ higher than the present average. Hao also proposed that the descendants of "Shandingdong man" began their new life in this environment, on the terraces of the Qingshui River. Official excavation of the Donghulin Site had not yet been carried out, and the geomorphology, depositional strata and cultural characteristics were not clear; thus Hao's research can be termed a pilot study. During 2000-2008, we carried out paleoenvironmental research at Donghulin, to explore the living environment of "Donghulin man", and to understand the environmental background of the cultural transition from Paleolithic to Neolithic.

\section{Geomorphological structure of the site}

The site is located to the northwest of Donghulin Village, at $360 \mathrm{~m}$ in altitude. The Qingshui River runs to the south of the village. On a rocky hill to the south of the river are a loess plateau and three river terraces.

The loess plateau is $32 \mathrm{~m}$ above the riverbed, and $16-100 \mathrm{~m}$ in width. The surface of plateau has been transformed into artificial terraces. The front edge of the plateau is exposed with a $2-4 \mathrm{~m}$ high, steep profile, while the back edge joins the rocky hill. The plateau is mainly composed of Malan loess, inside of which there are two layers of paleosol. The upper layer of paleosol is $0.50 \mathrm{~m}$ thick, red-brown in color and dense, and has been dated to $21.05 \pm 0.41 \mathrm{ka}$ BP using thermoluminescence dating (TL). The lower layer of paleosol is $0.50 \mathrm{~m}$ thick, red-brown in color and dense, and the TL age is $62.9 \pm 1.93 \mathrm{ka} \mathrm{BP}[18,19]$. The top of the plateau is covered with 1-2-m-thick Holocene loess.

Below the loess plateau are three river terraces. The terrace 3 is about $30 \mathrm{~m}$ in width, $24 \mathrm{~m}$ higher than the riverbed, and is a base terrace of Malan loess. In the terrace sediments (4-5 $\mathrm{m}$ thick), a dual structure is clearly visible. The Donghulin Site is located on the river terrace 3, and the relics are mainly found in the river deposits that comprise this terrace (Figure 1).

\section{Stratigraphy and sediments}

A typical profile is the west wall of T8, in the east of the site. This is $5.86 \mathrm{~m}$ thick, and divided into 12 layers (from top to bottom):

1. Yellow-grey loess sediments, with loose texture and mural joint structure, including small caliche nodules. The lower sediments have paleosol layers $\left(\mathrm{L}_{0} \mathrm{~S}\right)$ formed during the Holocene.

$150 \mathrm{~cm}$

2. Yellow-grey silt, including a little charcoal, small gravel, caliche nodules, and also a few stone implements. $36 \mathrm{~cm}$

3. Hard, brown-grey clay, with a little gravel at the bottom, and also stone implements, animal bones, and charcoal. $16 \mathrm{~cm}$

4. Yellow-grey silt, including a lot of white carbonate fake fungi, a few brown lumps and small gravels $(0.5 \mathrm{~mm})$. No cultural remains were observed.

$36 \mathrm{~cm}$

5. Brown-grey clayey silt, with vertical joints, containing a lot of small gravel $(1-2 \mathrm{~cm})$, and relatively large limestone breccia $(5-6 \mathrm{~cm})$. A large number of cultural remains were recovered, including bone fragments, charcoal, snails, shells, and a few burnt soil particles. Many ash heaps and ash pits were found distributed over the surface of this layer, indicating that this was an activity surface. $\quad 60 \mathrm{~cm}$

6. Yellow-brown fine sand, with small-scale oblique bedding, including a few pieces of charcoal, much tiny gravel, and large quantities of shells. There were small scale sand ridges on the top surface. This layer was without cultural remains except for a tomb (M2) near the surface. $16 \mathrm{~cm}$

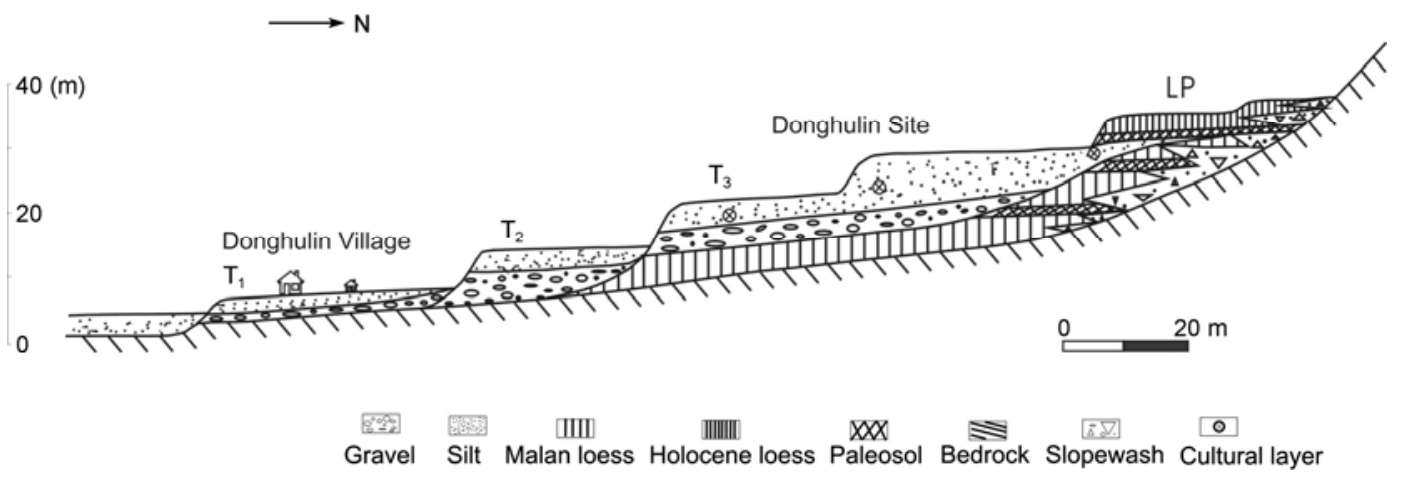

Figure 1 Geomorphological map of the Donghulin Site, Zhaitang. 
7. Yellow-brown fine sand, with a little small gravel, visible but small oblique bedding, and also charcoal and a few shells. In the northern part there was an ash heap $(80 \mathrm{~cm}$ diameter, $16 \mathrm{~cm}$ high) near the surface.

$12 \mathrm{~cm}$

8. Chocolate-brown clayey silt, including large quantities of white carbonate fake fungi, and a few rounded gravels. Cultural remains are abundant, including stone artifacts (stone saddle-quern), pottery, animal bones, human bones, shells, and charcoals. Many ash heaps (HD1-5, HD11) were found distributed across the top of this layer, indicating an activity surface. $\quad 28 \mathrm{~cm}$

9. Chocolate-brown clayey silt, compact, and with locally horizontal beddings, containing large quantities of white carbonate fake fungi, a little grey-green small breccia, and caliche nodules. A few animal bones, shells, and a little charcoal were found. Some ash pits (H5), ash heaps (HD12, F2), and tombs (M1), were distributed across the top of this layer, indicating an activity surface. $\quad 56 \mathrm{~cm}$

10. Yellow-brown fine sand, hard, and dark, including a large number of carbonate spots and nodules, and a little small gravel ( $2 \mathrm{~mm}$ in size). $\quad 16 \mathrm{~cm}$

11. Gravel, mixed with thin pieces of clayey silt, including various types of gravel: grey-green to purple-red volcanic rock, and some limestone. These were $2-5 \mathrm{~cm}$ in diameter, well rounded, of grade II-III.

$60 \mathrm{~cm}$

12. Yellow-grey Malan loess, mixed with brownish-red paleosol. An erosion surface is obvious between this and the overlying layer, indicating the base of the terrace. $100 \mathrm{~cm}$

We have concluded that layers 2-10 are river sediment comprising the terrace 3 . Layer 1 is loess sediment formed in the Holocene, which has accumulated after the formation of the terrace. Layer 12 is Malan loess sediment, forming the base of the terrace.

Dating indicated an AMS ${ }^{14} \mathrm{C}$ age of $9570 \pm 70$ a $\mathrm{BP}$ for layer 9 (at the bottom of the river sediment). The calendar age was $11090 \mathrm{cal}$ a BP. The AMS ${ }^{14} \mathrm{C}$ age of layer 2 (at the top of the river sediment) was $8535 \pm 80$ a $\mathrm{BP}$, while the calendar age was $9560 \mathrm{cal}$ a BP (Table 1). We can conclude that the river cut down around $11090 \mathrm{cal}$ a BP, and the terrace sediment formed between 11100 and 9600 cal a BP, corresponding to the warming period after the Younger Dryas. Human remains were mainly found in the terrace deposits. We chose this river sediment as the focus of our exploration of the environment of "Donghulin man". We thus collected a series of samples, carried out granularity analysis, and spore and pollen analyses in our laboratory, in the hope of gaining paleoenvironmental information.

\section{Granularity analysis}

Granularity analysis is an important way of researching the hydrology and landform evolution of a river. Grain size is measured and grain size frequency curves are created; dividing the sedimentary facies and microfacies of river sediment [21]. Human remains at the Donghulin Site were mainly found deposited on terrace 3 , and were in different layers. As a result, we were able to speculate on the position of landforms during the different periods in which "Donghulin man" lived, and also the changing course or the river. We were thus able to explore the geomorphological paleoenvironment of "Donghulin man".

Sixty-eight continuous samples were collected from the top of layer 2 to the bottom of layer 10; the width of each sample was $4 \mathrm{~cm}$, the total height sampled was $272 \mathrm{~cm}$ (layer 11 was river deposited gravel, so samples were not collected from this layer). A particle size analyzer (RS 1000, made by Malvern Corp. of England) was then used, grain size was examined, and frequency curves were drawn.

\subsection{Grain size}

We chose grain size parameters such as average size, modal particle size, median size, standard deviation, sorting

Table 1 AMS ${ }^{14} \mathrm{C}$ dating data of the profile at the Donghulin Site ${ }^{a)}$

\begin{tabular}{|c|c|c|c|c|c|}
\hline \multirow{2}{*}{ Layer } & \multirow{2}{*}{ Lab. No. } & \multirow{2}{*}{ Material } & \multirow{2}{*}{ AMS ${ }^{14} \mathrm{C}$ age (a BP) } & \multicolumn{2}{|c|}{ Calendar age (cal a BP) } \\
\hline & & & & $68.2 \%$ probability & $95.4 \%$ probability \\
\hline 2 & BAO7788 & charcoal & $8535 \pm 80$ & $9560(68.2 \%) 9440$ & $\begin{array}{l}9350(1.1 \%) 9320 \\
9700(95.4 \%) 9400\end{array}$ \\
\hline 3 & BA05890 & charcoal & $8775 \pm 40$ & $9890(68.2 \%) 9690$ & $\begin{array}{l}10150(2.3 \%) 10050 \\
9950(93.1 \%) 9550\end{array}$ \\
\hline 4 & BA02146 & charcoal & $8780 \pm 90$ & $\begin{array}{l}10150(6.3 \%) 10050 \\
9950(61.9 \%) 9600\end{array}$ & $10200(95.4 \%) 9550$ \\
\hline 5 & BAO5891 & charcoal & $8805 \pm 50$ & $\begin{array}{l}10120(7.2 \%) 10090 \\
9920(65.5 \%) 9700\end{array}$ & $10200(95.4 \%) 9550$ \\
\hline 7 & BA05887 & charcoal & $9155 \pm 40$ & $\begin{array}{l}10380(26.5 \%) 10310 \\
10300(41.7 \%) 10240\end{array}$ & $\begin{array}{l}10480(1.2 \%) 10460 \\
10430(94.2 \%) 10230\end{array}$ \\
\hline 8 & BA02150 & charcoal & $9180 \pm 80$ & $\begin{array}{l}10480(2.3 \%) 10460 \\
10420(65.9 \%) 10240\end{array}$ & $10560(95.4 \%) 10220$ \\
\hline 9 & BA03420 & M1 human bone & $9570 \pm 70$ & $\begin{array}{l}11090(38.4 \%) 10920 \\
10890(29.8 \%) 10860\end{array}$ & $11170(95.4 \%) 10700$ \\
\hline
\end{tabular}

a) Tested in the Chronology Laboratory and AMS Laboratory of Peking University. The half-life of ${ }^{14} \mathrm{C}$ is 5568 years. BP represents the time up to 1950. Calibration involved an IntCal04 curve [20] and OxCal v3.10 (Ramsey B. Christopher 2000 OxCal V3.5, online: http://rlaha.ox.ac.uk/orau.html). 
coefficient, skewness, and kurtosis (Table 2). The grain size values obtained were coincident with field observations (Figure 2). The profile was able to be divided into two parts, with a boundary at the top of layer 8 . In the lower part, layers 8-10 showed the smallest grain size and worst sorting, making a grain size cycle which was rough in the lower part and fine in the upper part, with the lower gravel layer 11 . In the upper part, layers 6-7 showed the largest grain size and best sorting except for the gravel layer. However, in layers $3-5$, the grain size was smaller and the particles were less well sorted; these also formed a grain size cycle which was rough in the lower part and fine in the upper part (Figure 2).

\subsection{Characteristics of grain size curves}

By analysis of the grain-size frequency curves and the probability curves, we were able to divide the samples into two types. Type B can be further divided into two subtypes, indicating different depositional environments [22-24] (Table 3).

Type A. Grains were coarse, and gritty. The frequency curve is bimodal and the distribution shows a positive skew. The peak grain size was 4-4.5 $\Phi$. The coarse tail is steep, forming a low peak between $-1-1 \Phi$; the fine tail is steep in the upper part and flat in the lower part, forming a gentle plateau between 6-7 $\Phi$. The grain size probability curve is a three-step curve. The rolling section $(-1.0-1.0 \Phi)$ is $1 \%-$ $5 \%$, the rate of slope is large, indicating good sorting. The saltation section (1-5.0 Ф) comprises about 60\%-70\%, and is composed of two parts with different slope rates. This indicates a reciprocating movement in the stream. The suspension section $(>5.0 \Phi)$ is around $30 \%$, the slope rate is small, indicating bad sorting. The high peak of the coarse tail in the frequency curve, the existence of the rolling section, and the major saltation section in the probability curve (composed of two parts with different rates of slope), indicate that the water was traveling quickly, and most of the grains underwent saltation, influenced by the reciprocating movement of the water. The two parts with different rates of slope indicate beach sediments. Type A only appears in layers 6 and 7.

Type B. Grains were fine and the major component was silty sand. The curve has unimodal distribution. Peak grain size was about $4.5 \Phi$. The coarse tail is steep; the fine tail is steep in the upper part (4.5-6.0 $\Phi)$ and flat in the lower part $(6-10 \Phi)$. The probability curve of grain size shows a two-step pattern. The major part is composed of a saltation section and suspension section, and does not have a rolling

Table 2 Mean grain size values

\begin{tabular}{|c|c|c|c|c|c|c|c|c|c|c|}
\hline \multirow[b]{2}{*}{ Layer } & \multicolumn{7}{|c|}{ Grain size parameter } & \multicolumn{2}{|c|}{ General characteristics } & \multirow{2}{*}{$\begin{array}{l}\text { Grain size } \\
\text { cycle }\end{array}$} \\
\hline & $\begin{array}{l}\text { Average } \\
\text { size }(\Phi)\end{array}$ & $\begin{array}{c}\text { Modal } \\
\text { size }(\Phi)\end{array}$ & $\begin{array}{l}\text { Median } \\
\text { size }(\Phi)\end{array}$ & $\begin{array}{l}\text { Standard } \\
\text { deviation }\end{array}$ & $\begin{array}{c}\text { Sorting } \\
\text { coefficient }\end{array}$ & Skewness & Kurtosis & Granularity & Sorting & \\
\hline 2 & 5.01912 & 4.20766 & 4.67369 & 1.53128 & 1.95551 & 0.36805 & 1.07053 & smaller & worse & \\
\hline 3 & 5.06734 & 4.23913 & 4.71964 & 1.53330 & 1.97019 & 0.36771 & 1.05553 & smaller & worse & II 2 \\
\hline 4 & 4.96770 & 4.21747 & 4.63900 & 1.48669 & 1.87412 & 0.37231 & 1.12172 & bigger & better & \\
\hline 6 & 4.37485 & 4.06869 & 4.21382 & 1.83786 & 1.89812 & 0.13599 & 1.47155 & biggest & best & II 1 \\
\hline 7 & 4.68734 & 4.08965 & 4.38657 & 1.52564 & 1.77652 & 0.32775 & 1.33205 & & & \\
\hline 8 & 5.36085 & 4.36688 & 5.05615 & 1.58848 & 2.20705 & 0.29438 & 0.90435 & smallest & worst & \\
\hline 9 & 5.42561 & 4.4918 & 5.13782 & 1.57602 & 2.1585 & 0.28515 & 0.93081 & & & I \\
\hline 10 & 5.48268 & 4.56683 & 5.21631 & 1.5608 & 2.14041 & 0.27187 & 0.93376 & & & \\
\hline
\end{tabular}

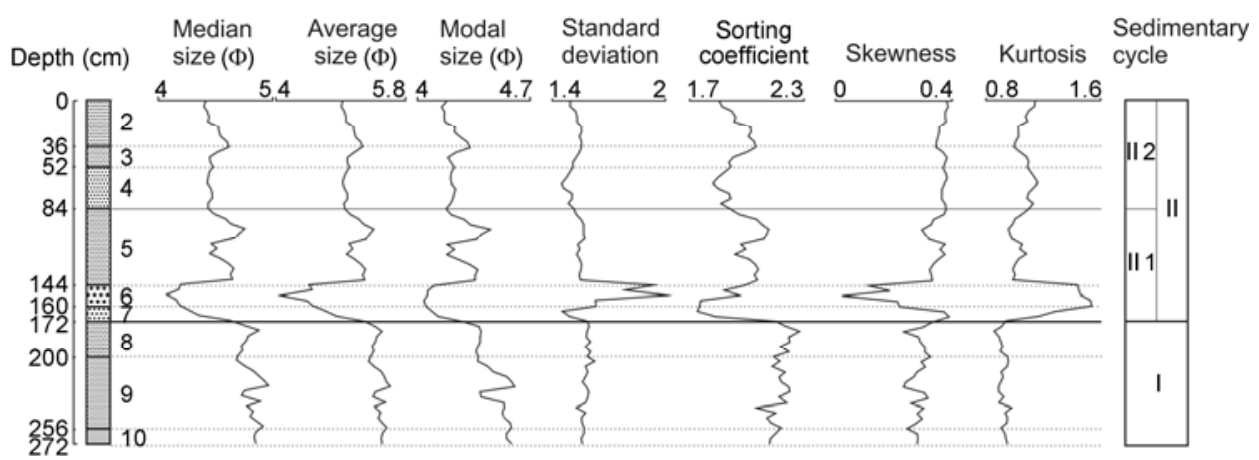

Figure 2 The curve lines of grain size parameters of layers 2-10. 
Table 3 Characteristics of grain size from different deposition layers

\begin{tabular}{|c|c|c|c|c|c|c|c|c|c|c|c|}
\hline \multirow[b]{2}{*}{ Type } & \multicolumn{5}{|c|}{ Grain size frequency curve } & \multicolumn{4}{|c|}{ Grain size probability curve } & \multirow[b]{2}{*}{ Layer } & \multirow{2}{*}{$\begin{array}{l}\text { Depositional } \\
\text { environment }\end{array}$} \\
\hline & Kurtosis & Main peak $(\Phi)$ & Skewness & Coarse part & Fine part & Figure & $\begin{array}{c}\text { Rolling } \\
\text { section }(\Phi)\end{array}$ & $\begin{array}{c}\text { Saltation } \\
\text { section }(\Phi)\end{array}$ & $\begin{array}{l}\text { Suspension } \\
\text { section }(\Phi)\end{array}$ & & \\
\hline A & two peaks & 4.3 narrow & positive & $\begin{array}{l}\text { steep, } \\
\text { subpeak }\end{array}$ & $\begin{array}{l}\text { leaning } \\
\text { flat table }\end{array}$ & $\begin{array}{l}\text { three- } \\
\text { scetions }\end{array}$ & $\begin{array}{l}-1.0-1.0 \\
(2 \%-5 \%)\end{array}$ & $\begin{array}{c}1-5.0 \\
(70 \%)\end{array}$ & $\begin{array}{c}>5.0 \\
(30 \%)\end{array}$ & $6-7$ & $\begin{array}{l}\text { beach of } \\
\text { riverbed }\end{array}$ \\
\hline B1 & one peak & 4.5 wide & positive & steep & leaning flat & $\begin{array}{c}\text { two- } \\
\text { sections }\end{array}$ & no & $\begin{array}{c}2.3-5.0 \\
(50 \%)\end{array}$ & $\begin{array}{l}>5.0 \\
(50 \%)\end{array}$ & $9-10,5$ & $\begin{array}{l}\text { floodplain, } \\
\text { nearshore } \\
\text { environment }\end{array}$ \\
\hline B2 & one peak & 4.5 narrow & positive & steep & $\begin{array}{l}\text { leaning } \\
\text { flat table }\end{array}$ & $\begin{array}{c}\text { two- } \\
\text { sections }\end{array}$ & no & $\begin{array}{c}2.3-5.0 \\
(50 \%)\end{array}$ & $\begin{array}{l}>5.0 \\
(50 \%)\end{array}$ & $4-2,8$ & flood plain \\
\hline
\end{tabular}

section. The saltation section $(2.3-5.0 \Phi)$ is about $40 \%-$ $50 \%$, and is composed of two parts with differing rates of slope, indicating reciprocating movement. The suspension section $(>5.0 \Phi)$ is around $50 \%$. The slope rate is small, indicating bad sorting. Because the rolling section is missing, the saltation section (composed of two parts with differing rates of slope) is equivalent to the suspension section. We therefore speculated that this part was floodplain sediment.

Type B was able to be divided into two subtypes. The frequency curve of grain size of Type B1 has a wide main peak, and the fine part forms a nicely graded curve, showing graded suspension, an indication of poor sorting and floodplain sediment (Figure 3, middle). Type B1 can usually be seen in layers 9-10 and the lower part of layer 5. The curve of Type B2 has a narrow main peak, and in the fine part there is an obvious flat part between 6-8 $\Phi$, indicating good sorting and floodplain sediment (Figure 3, lower). Type B2 can usually be seen in layer 8 , in the upper part of layer 5 , and in layers 2-4.

Based on the grain size analysis and field observations, we can divide the river sediments into two parts. The lower part, from the gravel layer (layer 11) to layer 8, indicates a fluvial course of riverbed deposition (layer 11) to a nearshore deposition (layers 9-10), to farshore deposition (layer 8 ). The upper part, from gravel layers 7 to 2 , indicates another fluvial course of beach deposition (layers 6-7), to nearshore deposition (layer 5), to farshore deposition (layers $2-4)$. The dating of layer 8 indicates that the boundary between the two parts was around 10500 cal a BP. The distribution of human remains shows that "Donghulin man" mainly lived during the flood plain depositional period, especially the farshore depositional period. These humans lived on the floodplain after floods had retreated, and changed their encampments as the river course and the landforms changed, probably having a semi-sedentary lifestyle.

\section{Sporopollen analysis}

Sporopollen analysis is able to reflect the composition and change of vegetation in a region, and hence this is an important way to explore paleoenvironment and paleoclimate.

We collected 68 samples from the bottom of layer 10 to the top of layer 2 in the north profile of grid 8 at the Donghulin Site. Each sample was $4 \mathrm{~cm}$ in thickness (as were the grain size samples). During sample collection, we attempted to avoid the human activity surfaces, and thus reduce the influence of human disturbance. Samples were prepared for analysis (acid-alkali chemical reactions and д-6 heavy liquid flotation [25]).

Thirty-one families and genera were identified. Woody plants were represented by 12 families or genera, including Pinus, Moraceae, Quercus, Juglans, Betula, Rhus, Tilia, Oleaceae, Ulmus, Salix, Carpinus, and Pressaceae. Herbaceous pollen indicated 17 families or genera, including $\mathrm{Ar}$ temisia, Gramineae, Chenopodiaceae, Cruciferae, Leguminosae, Ranunculaceae, Thalictrum, Solanaceae, Compositae, Convolulaceae, Humulus, Labiaceae, Cyperaceae, Scrophulariaceae, Polygonum, Rosaceae, Euphorbiaceae. Fern spores were represented by Polypodiaceae and Selaginella. Today these families and genera are common in the area.

Pollen and spore concentrations in all 68 samples were low (no greater than 23 grains/g), indicating that the vegetation was probably sparse. Abundance of herbs, woody plants and ferns was relatively consistent between samples. The major components were herbs $(80 \%-90 \%$ of samples, with a maximum of $100 \%$ ), and the main genus was Artemisia. The Chenopodiaceae and Gramineae were less well represented; the A/C (the ratio of Artemisia/Chenopodiaceae) of most samples was greater than 1 . Woody plants were not common (only 0-20\%), and were mainly Pinus, Pressaceae and broad-leaf trees. A few ferns spores (0-3.7\%) appeared in some samples; ferns might have grown in small ponds that remained on the flood plain. It is thought that the pollen of herbs and broad-leaf trees is usually dropped on or near its origin, however, the pollen of Pinus species has air cells enabling it to be wind transported for long distances [26]. The spore and pollen analysis showed there were only a few Pinus, so we think the result could basically represent the vegetation of Donghulin area.

Based on the pollen and spore analysis, we divided the profile into seven pollen-spore zones (Figure 4, Table 4): 

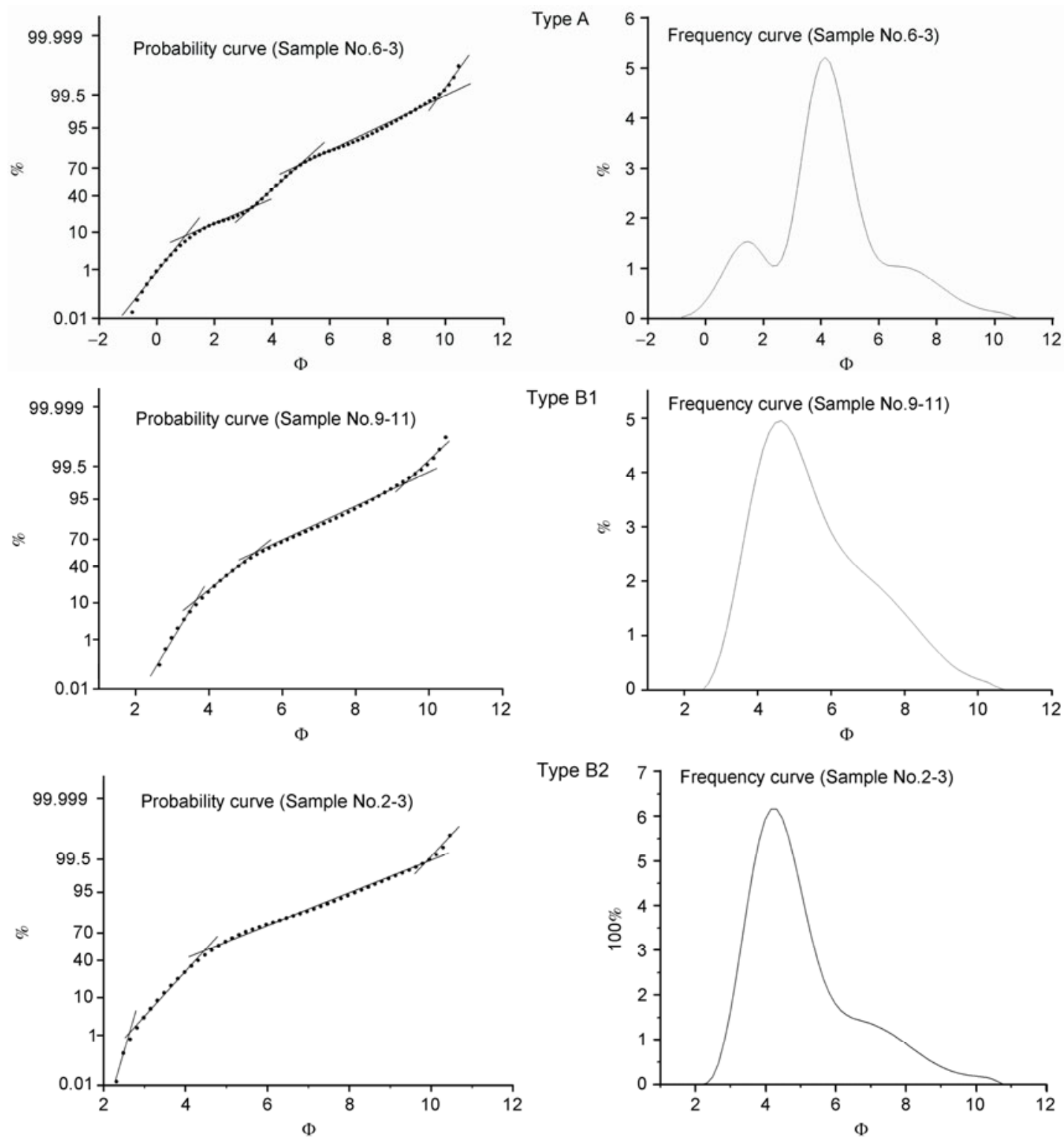

Figure 3 Typical grain size probability curves and frequency curves of different sediments. Type A: The probability curve (left) and the frequency curve (right) of the grain size of beach sediments; Type B1: the probability curve (left) and the frequency curve (right) of the grain size of nearshore sediments; Type B2: the probability curve (left) and the frequency curve (right) of the grain size of farshore sediments.

Zone I (0-52 cm, corresponding to layers 2 and 3). The pollen concentration was $6.3-47.8$ grains/g. The major component was herbs $(71.1 \%-100 \%)$, and the main genus was Artemisia (44.3\%-61.9\%). The Chenopodiaceae (3.6\%$20.4 \%)$ and Gramineae $(6.0 \%-21.4 \%)$ were less well represented, and the A/C was large (2.28-16.00). Other herbs included members of the Compositae, Ranunculaceae, Thalictrum, Rosaceae, Solanaceae, Cruciferae, Leguminosae, Humulus, Convolulaceae, and Cyperaceae. Woody plants comprised 0-26.8\% of the pollen. Besides Pinus and Pressaceae, many deciduous broad-leaf trees, such as Betula, Carpinus, Quercus, Juglans, Ulmus, Rhus, Salix, Moraceae, and Oleaceae were identified. Ferns spores represented 0-2.9\%, and were of Selaginella and Polypodiaceae, both of which were widely recorded. This pollen composition indicates a temperate meadow steppe under warm and wet conditions.

Zone II (52-120 cm, equivalent to layer 4 and upper layer 5). The pollen concentration was $8.1-18.4$ grains/g. The major component was herbs $(88.2 \%-100 \%)$, of which the main genus was Artemisia (36.4\%-70.4\%). Chenopodiaceae $(11.1 \%-39.4 \%)$ and Gramineae $(2.8 \%-22.9 \%)$ were less well represented, and the A/C was large (0.83-6.33). Other herbs included members of the Ranunculaceae, Thalictrum, Solanaceae, Cruciferae, Leguminosae, Humulus, Scrophulariaceae, and Labiaceae. There were only small amounts of woody plant pollen (0-11.5\%), comprised of Pinus, and a few pollen grains of Rhus and Moraceae. The 


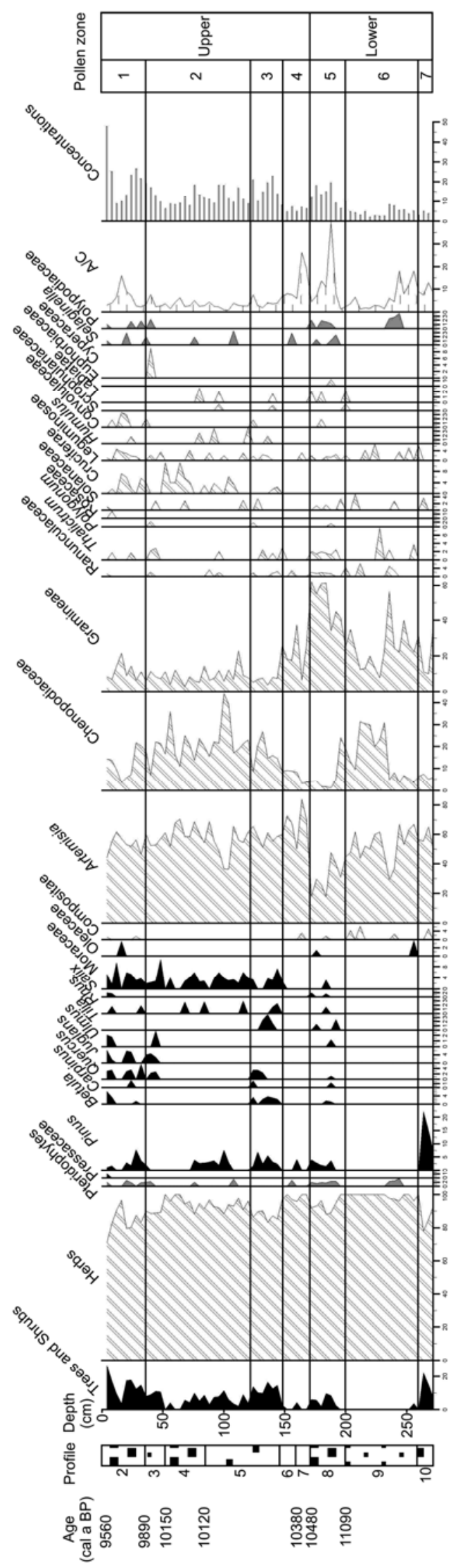

Figure 4 Pollen diagram of the profile at the Donghulin Site. only fern spores were from Selaginella (0-3.4\%), and were unevenly distributed. This configuration suggests a temperate grassland environment with a warm and dry climate.

Zone III (120-144 cm, corresponding to lower layer 5). The pollen concentration was 10.2-22.8 grains/g. The major component was herbs $(83.3 \%-90.2 \%)$, and the main genus was Artemisia (51.2\%-65.5\%). The Chenopodiaceae $(8.6 \%-$ $26.8 \%)$ and Gramineae $(3.7 \%-7.9 \%)$ were less well represented, and the A/C was large (1.91-7.60). Other herbs included members of the Ranunculaceae, Thalictrum, Leguminosae, Polygonum, Solanaceae, Cruciferae, Humulus, Convolulaceae, Scrophulariaceae, and Labiaceae. The numbers of woody plants increased $(9.8 \%-16.7 \%)$. Besides $P i$ nus and Pressaceae, there were many deciduous broad-leaf trees, including Quercus, Betula, Tilia, Carpinus, Rhus, and Moraceae. No fern spores were found. This configuration indicates a temperate meadow steppe under warm and wet conditions.

Zone IV (144-172 cm, corresponding to layer 6 and layer $7)$. The pollen concentration was $4.8-12$ grains/g. The dominant component was herbs $(92 \%-100 \%)$, of which the main genus was Artemisia (18\%-83.9\%). The Gramineae $(6.5 \%-62 \%)$ and Chenopodiaceae $(3.2 \%-9.1 \%)$ were less well represented, and the $\mathrm{A} / \mathrm{C}$ was large (4.50-26.22). There were a few other herbs including members of the Compositae, Ranunculaceae, Thalictrum, Leguminosae, Labiaceae. There were only a few woody plants $(0-6.0 \%)$, including Pinus and Moraceae. Ferns, including members of Selaginella and the Polypodiaceae, were sparse (0-2.9\%). This configuration indicates a warm and dry temperate grassland environment.

Zone V (172-200 cm, corresponding to lower layer 8). The pollen concentration was $6.5-19.6$ grains/g. The dominant component was herbs $(88.7 \%-100 \%)$, of which the main family was the Gramineae $(25.5 \%-61.3 \%)$. Artemisia $(17.7 \%-44.7 \%)$ and Chenopodiaceae $(1.2 \%-24.1 \%)$ were less well represented, and the A/C was large (1.28-39.67). Other herbs included members of the Ranunculaceae, Thalictrum, Polygonum, Compositae, Leguminosae, Solanaceae, Convolulaceae, Labiaceae, Euphorbiaceae, and Scrophulariaceae. The numbers of woody plants increased (0-9.7\%). Besides Pinus, there were several deciduous broad-leaf trees, such as members of Betula, Carpinus, Quercus, Ulmus, Tilia, Salix, Rhus, Moraceae, and Oleaceae. Fern spores also increased in abundance (0-2.5\%), and were mainly Selaginella and Polypodiaceae. This configuration indicates a warm and wet temperate meadow steppe environment.

Zone VI (200-256 cm, corresponding to layer 9). The pollen concentration was 2.0-8.6 grains/g. The dominant component was herbs $(96.3 \%-100 \%)$, of which the main genus was Artemisia (29.3\%-66.7\%). The Gramineae (7.7\%$56.1 \%)$ and Chenopodiaceae $(3.7 \%-30.8 \%)$ were less well represented, and the A/C was large (1.40-18.03). A few other herbs including members of the Compositae, Ranunculaceae, Thalictrum, Leguminosae, and Solanaceae, were 
Table 4 Characteristics of pollen and spores in each zone and likely environmental conditions

\begin{tabular}{|c|c|c|c|c|c|c|c|}
\hline \multirow{2}{*}{ Profile } & \multirow{2}{*}{ Zone } & \multirow{2}{*}{ Layer } & \multicolumn{4}{|c|}{ Spore and pollen characteristic } & \multirow{2}{*}{ Environment } \\
\hline & & & Major & Woody plant & Fern & $\mathrm{A} / \mathrm{C}$ & \\
\hline \multirow{4}{*}{$\begin{array}{l}\text { Upper } \\
\text { part }\end{array}$} & I & $3-2$ & $\begin{array}{l}\text { Artemisia-Gramineae- } \\
\text { Chenopodiaceae, other herbs (many) }\end{array}$ & $\begin{array}{l}\text { the proportion is } 0-26.8 \% \text {, containing } \\
\text { many deciduous broad-leaf trees }(8)\end{array}$ & many & $\begin{array}{c}2.28-16.00 \\
\text { mean value } 5.41\end{array}$ & $\begin{array}{c}\text { warm and wet } \\
\text { temperate meadow } \\
\text { steppe } \\
\end{array}$ \\
\hline & II & $5_{\mathrm{up}}-4$ & $\begin{array}{l}\text { Artemisia- } \\
\text { Chenopodiaceae-Gramineae, } \\
\text { other herbs (a few) }\end{array}$ & $\begin{array}{l}\text { the proportion is } 0-11.5 \% \text {, containing a few } \\
\text { deciduous broad-leaf trees (Rhus, Moraceae) }\end{array}$ & a few & $\begin{array}{c}0.83-6.33 \\
\text { mean value } 2.96\end{array}$ & $\begin{array}{l}\text { warm and dry } \\
\text { temperate grass- } \\
\text { land } \\
\end{array}$ \\
\hline & III & $5_{\text {low }}$ & $\begin{array}{l}\text { Artemisia- } \\
\text { Chenopodiaceae-Gramineae, } \\
\text { other herbs (many) }\end{array}$ & $\begin{array}{l}\text { the proportion is } 9.8 \%-16.7 \% \text {, containing } \\
\text { many deciduous broad-leaf trees }(6)\end{array}$ & no & $\begin{array}{c}1.91-7.60 \\
\text { mean value } 3.99\end{array}$ & $\begin{array}{c}\text { warm and wet } \\
\text { temperate meadow } \\
\text { steppe } \\
\end{array}$ \\
\hline & IV & $7-6$ & $\begin{array}{l}\text { Artemisia-Gramineae - } \\
\text { Chenopodiaceae, other herbs } \\
\text { (a few) }\end{array}$ & $\begin{array}{l}\text { the proportion is } 0-2.9 \% \text {, containing a few } \\
\text { deciduous broad-leaf trees (Salix) }\end{array}$ & some & $\begin{array}{l}4.50-26.22 \\
\text { mean value } \\
11.20\end{array}$ & $\begin{array}{l}\text { warm and dry } \\
\text { temperate grass- } \\
\text { land }\end{array}$ \\
\hline \multirow{3}{*}{$\begin{array}{l}\text { Lower } \\
\text { part }\end{array}$} & V & 8 & $\begin{array}{l}\text { Gramineae- } \\
\text { Artemisia-Chenopodiaceae, other } \\
\text { herbs (many) }\end{array}$ & $\begin{array}{l}\text { the proportion is } 0-9.7 \% \text {, containing several } \\
\text { deciduous broad-leaf trees ( } 4 \text { ) }\end{array}$ & many & $\begin{array}{c}1.28-39.67 \\
\text { mean value } \\
11.86\end{array}$ & $\begin{array}{l}\text { warm and wet } \\
\text { temperate meadow } \\
\text { steppe }\end{array}$ \\
\hline & VI & 9 & $\begin{array}{l}\text { Artemisia-Gramineae- } \\
\text { Chenopodiaceae, other herbs (a few) }\end{array}$ & $\begin{array}{l}\text { the proportion is } 0-3.7 \% \text {, no deciduous } \\
\text { broad-leaf tree }\end{array}$ & a few & $\begin{array}{c}1.40-18.03 \\
\text { mean value } 6.33\end{array}$ & $\begin{array}{l}\text { warm and dry } \\
\text { temperate grass- } \\
\text { land }\end{array}$ \\
\hline & VII & 10 & $\begin{array}{l}\text { Artemisia-Gramineae- } \\
\text { Chenopodiaceae, other herbs (a few) }\end{array}$ & $\begin{array}{l}\text { the proportion is } 2.6 \%-2.72 \% \text {, no deciduous } \\
\text { broad-leaf tree }\end{array}$ & no & $\begin{array}{c}7.51-13.00 \\
\text { mean value } 9.52\end{array}$ & $\begin{array}{l}\text { cool and dry tem- } \\
\text { perate grassland }\end{array}$ \\
\hline
\end{tabular}

also identified. Woody plants were only represented by a few Oleaceae. Fern spores were found in the middle part of the zone, but only Polypodiaceae $(0-3.7 \%)$. This record points to a warm and dry temperate grassland.

Zone VII (256-272 cm, corresponding to layer 10). The pollen concentration was 3.1-10.1 grains/g. The major component was herbs $(77.8 \%-100 \%)$, of which the main genus was Artemisia (51\%-65\%). The Gramineae (10.0\%$35.3 \%)$ and Chenopodiaceae (5.0-7.4) were less well represented, and the A/C was large (7.51-13.00). There were also a few Leguminosae and Solanaceae. Woody plant pollen (0-22.2\%) was solely from Pinus. No fern spores were found. This indicates an environment of cool and dry temperate grassland.

From the overall patterns indicated by the pollen and spore analysis, we can see that during the period of "Donghulin man" (11100-9600 cal a BP), the vegetation mainly included Artemisia, but that some members of the Chenopodiaceae and Gramineae were present. A few deciduous broad-leaf trees were also present, indicating warm to cool, dry temperate grassland, and warm and wet, temperate meadow steppe environments. The latter environment was more common during the late "Donghulin period" (105009600 cal a BP) (Table 4).

\section{Discussion}

The Donghulin Site is an early Neolithic site, with clear landforms, a complete stratum and abundant cultural relics. From analysis of the stone implements unearthed here, ar- chaeologists have speculated that in the Donghulin period, the microlith, an important symbol of Paleolithic-Neolithic transition, was well developed. The number of neoliths increased as well, indicating a typical Paleolithic-Neolithic transition culture.

There are many reasons for the Paleolithic-Neolithic transition. Our research shows that "Donghulin man" lived during the warm period following the Younger Dryas. The climate is the same in other places of North China [27-30]. The environment clearly changed during this period; the land was initially covered by dry temperate grassland and transformed to wet temperate meadow steppe. Previous analysis of the physiographic stages shows that around 10000 a BP, along with the climate becoming warmer and wetter, the river cut down through the intermountain loess plain which had emerged during the Malan period, and formed a new river valley and Malan loess platform along both sides (this was called the "Banqiao Erosion"). Aggradation was strong in the new valley, and thick fluvial deposits accumulated, forming widespread floodplains (this was called the "Gaolan Accumulation period") [31-34].

Other Paleo-Neolithic transition sites in the North China area, such as the Yujiagou Site in Yuanyang, Hebei Province; the Shizitan Site in Jixian, Shanxi Province; and the Lijiagou Site in Xinmi, Henan Province, are probably similar to the Donghulin Site. Places of human habitation all had a strong relationship with the valley formed by the Banqiao Erosion and the Gaolan Accumulation. We speculate that the warm period following the Younger Dryas, and also the river valley landscapes formed by the Banqiao Erosion, are probably the most important environmental factors during 
the transition from Paleolithic to Neolithic in this area.

\section{Conclusion}

Our integrated study included a geomorphological survey, profile observation, sediment analysis, and palynological analysis, and incorporated data from chronological dating and archaeological records. It is able to provide the following insights:

(1) "Donghulin man" occupied the site between 11100-9600 cal a BP. This was the warm period after the Younger Dryas, and the "Gaolan Accumulation" period following the "Banqiao Erosion".

(2) The remains of "Donghulin man" were mainly distributed in the river deposits on the terrace 3 of the Qingshui River; most are on top of floodplain sediments. This suggests that "Donghulin man" mainly lived on the floodplain of the paleo-Qingshui River, and probably changed encampments as the river and landforms changed.

(3) During the "Donghulin man" period, the climate was good; warm and dry to warm and wet. The vegetation was temperate grassland and changing to temperate meadow steppe. There were abundant animals and plants that were appropriate for human hunting and gathering.

(4) The geomorphology and climate changed around 10500 cal a BP, during the period of "Donghulin man". The river evolved from the first river course to the second one, and the warm and dry temperate grassland changed to warm and wet temperate meadow steppe. At the same time, the microlith, an important symbol of Paleolithic-Neolithic cultural transition, significantly developed. Further research is required to clarify the relationship between this changing culture and its changing environment.

Grain size analysis was conducted in the Land Surface Processes and Environmental Simulation Laboratory of Peking University. The ${ }^{14} \mathrm{C}$ dating was conducted in the Quaternary and Archaeological Chronology Laboratory, as in the Heavy-ion Accelerator Mass-spectrometry Laboratory, Peking University. Palynological analysis was done in the Hydrogeology and Engineering Geology Research Institute of the Chinese Academy of Science, Zhengding City. We express our thanks to the members of these institutions. This work was supported by the National Natural Science Foundation of China (40571168), and the National Science and Technology Supporting Project (2010BAK67B02).

1 Andersson J G. Topographical and archaeological studies in the Far East. In: Samlingarna Ö, ed. Bulletin of the Museum of Far Eastern Antiquities. Stockholm: BMFEA-Museum of Far Eastern Antiquities, Vol 11. 1939. 7-22

2 Ye L F. The geology of Xishan (His-Shan) or the Western Hills of Beijing (in Chinese). Mem Geol Surv China-Ser A, 1920, 1: 51-63

3 Bian M N, Yuan F L. Geomorphology and Archaeological research of Far East area (in Chinese). Geol Rev, 1940, 5: 119-131

4 Zhao X T, Li R Q. Quaternary deposit and stratum of Zhaitang area, Beijing (in Chinese). Collected Papers of Geology Research Institution of Chinese Academy of Sciences, 1981, 2: 112-122

5 Fu L X, Fu J M, Li R Q. Erosion and geomorphological environment evolution of Qingshui River, Xishan, Beijing (in Chinese). J Beijing Nor Univ (Nat Sci), 1998, 1: 119-123

6 Wei L Y. The environmental meaning of "Qingshui Erosion-Malan accumulation" physiographic stage cycle (in Chinese). Quat Res, 1998, 3: 284

7 Yin C M, Li R Q. The deposit and environment of Malan platform in Qingshui River, Xishan, Beijing (in Chinese). J Beijing Nor Univ (Nat Sci), 2000, 6: 835-839

8 Hao S G. Discovery course of Homo Donghulin (in Chinese). Fossil, 1988: 18-19

9 Zhou G X, You Y Z. Holocene tombs in Donghulin village, Beijing. Archaeology, 1972, 6: 12-15

10 Zhao C H. Prehistoric Donghulin Site in Mentougou District, Beijing City (in Chinese). Archaeology, 2006, 7: 3-8, 97-98

11 Xia Z K, Cheng G, Zheng G W, et al. Environmental background of evolution from the paleolithic to neolithic culture in Nihewan Basin, North China. Sci China Ser D-Earth Sci, 2001, 44: 779-788

12 Xia Z K, Cheng G, Cheng F Y, et al. Climate background of the Paleolithic-Neolithic cultural transition during the deglaciation in the Middle Reaches of the Yellow River. Chin Sci Bull, 2002, 47: 71-75

13 Mannion A M. Global Environmental Change. Singapore: Longman, 1997. 42-77

14 Wang W Y, Liu J Q, Negenbank J, et al. Two-step changes of summer monsoon in East Aisa during the Last glaciation-record in tropical Huguangyan Maar Lake (in Chinese). Chin Sci Bull, 2000, 45: 860-864

15 Zhou W J, An Z S, Poter S C, et al. Contrast of the climate events between East Aisa and Norwegian Sea during the Last glaciation (in Chinese). Sci China Ser D-Earth Sci, 1997, 27: 260-264

16 Blaine E. Climate Course and Climate Change (in Chinese). Beijing: Science Press, 2004. 83-97

17 Zhao C H. Clear locus of Paleolithic-Neolithic transition (in Chinese). Relics from South, 1995, 1: 28-37

18 Hao S G, Ma X P, Yuan S X, et al. The Donghulin Woman from western Beijing: ${ }^{14} \mathrm{C}$ age and an associated compound shell necklace (in Chinese). Antiquity, 2001, 75: 517-522

19 Hao S G, Ma X P, Xia Z K, et al. The Early Holocene Loess Section in the Donghulin Site near Zhaitang in Beijing. Acta Geol Sin, 2002, 76: 420-430

20 Reimer P J, Baillie M G L, Bard E, et al. IntCal04 terrestrial radiocarbon age calibration, 0-26 cal kyr BP. Radiocarbon, 2004, 46: 10291058

21 Reading H G. Sedimentary Environments: Processes, Facies, and Stratigraphy. London: Blackwell Science, 1978

22 North Shaanxi Team of Chengdu Geological College. Deposition Grain Size Analysis and Application (in Chinese). Beijing: Geological Publishing House, 1976

23 Chen Z Y, Yan Q S. The structure of recent alluvial sedimentation of the Hutuo River on plain reach, Hebei Province (in Chinese). Sci Geogr Sin, 1982, 2: 210-221

24 Gao J, Yan Q S, Xu S Y. The relationship between sedimentary structures and hydrodynamics in the middle reach of the Luan River, Hebei Province (in Chinese). Acta Sediment Sin, 1983, 1: 27-41

25 Li Y, Wang N A, Xu H Q, et al. Investigation of Quarternary Pollen and Spores Extraction Methods in North China (in Chinese). Acta Sediment Sin, 2007, 25: 124-130

26 Zhou K S. Investigation and partial analysis of two buried peat moor near Beijing (in Chinese). Chin Quat Sci, 1965, 4: 118-134

27 Li W Y. Quaternary Vegetation and Environment of China (in Chinese). Beijing: Science Press, 1998

28 Li Y C, Wang K F, Zhang Y L. The evolution of paleo-vegetation and paleo-environment in Nanzhuangtou Site and their relationship with man activities (in Chinese). Mar Geol Quat Geol, 2000, 20: 23-30

29 Sun X J, Song C Q, Wang F Y. Vegetation history of the Shouth Platesu of China during the last 100000 years-pollen record of the loess profile in Weinan, Shaanxi Province (in Chinese). Chin Sci Bull, 1995, 40: 1222-1224 
30 Zhou K S. Pollen analysis of late Quaternary in Beijing Plain and its significance (in Chinese). Chin J Geol, 1978, 1: 57-66

31 Wu C. Landform Environment and Its Formation in North China (in Chinese). Beijing: Science Press, 2008. 422-463

32 Li J J, Kang C Y. Quaternary Glaciations, physiographic states and Loess record in China (in Chinese). Quat Sci, 1989, 3: 269-276
33 Li R Q, Qiu W L. Physiographic stages and their research in China (in Chinese). Quat Sci, 2005, 25: 676-685

34 Zhou K S. Local unconformity in North China of Late Holocenesome discussion on Banqiao Erosion (in Chinese). In: Liu J Q, Yuan B Y, eds. Chinese Quaternary Geology and Environment. Beijing: Ocean Press, 1997. 36-43

Open Access This article is distributed under the terms of the Creative Commons Attribution License which permits any use, distribution, and reproduction in any medium, provided the original author(s) and source are credited. 